\title{
The contribution of soil structural degradation to catchment flooding: a preliminary investigation of the 2000 floods in England and Wales
}

\author{
I.P. Holman ${ }^{1}$, J.M. Hollis ${ }^{2}$, M.E. Bramley ${ }^{3}$ and T.R.E. Thompson ${ }^{2}$ \\ ${ }^{1}$ Institute of Water and Environment, Cranfield University, Silsoe, Bedford, MK45 4DT, UK \\ ${ }^{2}$ National Soil Resources Institute, Cranfield University, Silsoe, Bedford, MK45 4DT, UK \\ ${ }^{3}$ Environment Agency, Head Office, Aztec West, Almonsbury, Bristol, BS32 4UD, UK \\ Email for corresponding author: i.holman@cranfield.ac.uk
}

\begin{abstract}
During the autumn of 2000, England and Wales experienced the wettest conditions for over 270 years, causing significant flooding. The exceptional combination of a wet spring and autumn provided the potential for soil structural degradation. Soils prone to structural degradation under five common lowland cropping systems (autumn-sown crops, late-harvested crops, field vegetables, orchards and sheep fattening and livestock rearing systems) were examined within four catchments that experienced serious flooding. Soil structural degradation of the soil surface, within the topsoil or at the topsoil/subsoil junction, was widespread in all five cropping systems, under a wide range of soil types and in all four catchments. Extrapolation to the catchment scale suggests that soil structural degradation may have occurred on approximately $40 \%$ of the Severn, $30-35 \%$ of the Yorkshire Ouse and Uck catchments and $20 \%$ of the Bourne catchment. Soil structural conditions were linked via hydrological soil group, soil condition and antecedent rainfall conditions to SCS Curve Numbers to evaluate the volume of enhanced runoff in each catchment. Such a response at the catchment-scale is only likely during years when prolonged wet weather and the timing of cultivation practices lead to widespread soil structural degradation. Nevertheless, an holistic catchment-wide approach to managing the interactions between agricultural land use and hydrology, allowing appropriate runoff (and consequent flooding) to be controlled at source, rather than within the floodplain or the river channel, should be highlighted in catchment flood management plans.
\end{abstract}

Keywords: flooding, soil structure, land management, Curve Number, runoff, agriculture

\section{Introduction}

During the autumn of 2000, England and Wales as a whole experienced the wettest conditions (September to November) for over 270 years (Environment Agency, 2001a). Repeated heavy rainfall in October and November caused significant, extensive and, in some cases, repeated flooding over large areas of the country. Over 10000 homes and businesses were flooded, train services were cancelled, major motorways closed and power services disrupted (Environment Agency, 2001a).

It was suggested repeatedly in the media that catchments such as the Severn, Yorkshire Ouse and Medway flooded because the soils were 'saturated' by the first storms in October and were unable to absorb further rainfall.

Prior to the autumn, the spring and early summer of 2000 were also particularly wet, with flooding occurring in several
English regions. Soils which are wet during critical times for land management operations, such as for ploughing or harvesting, can be prone to compaction and structural damage (Earl, 1997). Soil structural damage leads to a reduction in soil water storage and infiltration capacity (Horton et al., 1994), which reduces the inherent ability of the soil to absorb rain, leading to increased runoff.

The exceptional combination of a wet spring and a wet autumn during 2000, together with long term changes in farming practice, provided the potential for significant soil structural degradation, even where farmers followed Best Practice guidelines (Ministry of Agriculture, Fisheries and Food, 1998; Environment Agency, 2001b). If extensive, the resulting increased runoff may have contributed to the severe floods. This paper describes the results of a survey to ascertain the conditions of a range of soils under different 
cropping systems within catchments that experienced serious flooding and the possible consequent contribution of these soils to event runoff.

\section{Soil hydrological and agronomic background}

The speed with which water reaches the river network is influenced strongly by the nature and condition of the underlying soil (Boorman et al., 1995; U.S. Soil Conservation Service, 1986). A range of cropping and stock management systems in UK agriculture has the potential to modify soil hydrology significantly (e.g. Boardman, 1991, 1995; Chambers and Garwood, 2000), by impacting upon soil structural conditions. These impacts result mainly from the need for machinery or livestock to access land at times when soil is at, or approaching, its wettest season. Five main lowland agricultural management practices potentially pose a problem:

Cultivation of autumn-sown cereals, oilseed rape and field beans during the autumn when the soil is 'wetting up'. This can lead to compacted plough layers and tractor 'wheelings' and, particularly in the case of cereals, fields which are sparsely vegetated over the winter period and prone to capping (Kwaad, 1994) and erosion (Chambers and Garwood, 2000).

Harvesting operations for late-harvested crops such as maize, sugar beet and main crop potatoes using heavy machinery during late autumn and early winter, when the soils are likely to be at their 'field capacity' moisture state, leave some, or all of the field surfaces bare, compacted (Arvidsson, 2001) and rutted.

Cultivation of intensive crops of field vegetables where access to the land is often required through the winter period when soils are likely to be at their wettest. Harvested areas usually remain bare and compacted over the winter period (Harrod, 1994).

Farming systems with fruit orchards often maintain a minimum of vegetation in the rows between trees or bushes. The soil surface in these rows is often compacted, leading to a reduced infiltration capacity (Haynes, 1981), erosion (Boardman and Hazelden, 1986), and exposure to rainfall during the late autumn and winter periods due to the minimal interception by the trees or bushes.

Lowland sheep fattening and livestock rearing systems. A common practice in sheep fattening systems is to allow stock to feed on the vegetation left after harvesting sugar beet or to feed on fodder beet during the autumn and early winter periods when soil surfaces are bare. Also, in areas where grass growth starts early in the year or persists later in the year, stock may be kept on the land at times when the soil surface is at its wettest point in the annual hydrological cycle and thus most susceptible to compaction (Vallentine, 1990).

\section{Methodology}

The Severn, Yorkshire Ouse, Bourne and Uck catchments, which all experienced severe flooding during the late autumn and winter of $2000 / 2001$, were selected for study (Holman et al., 2002). The whole of the smaller catchments of the rivers Uck and Bourne, which are sub-catchments of the Medway, were investigated. Due to the size of the Severn and the Yorkshire Ouse catchments, field investigations were focused on three areas of $10 \mathrm{~km} \times 10 \mathrm{~km}$ (Fig. 1) within each. These areas were selected as representative of the range of soils and lowland agricultural management practices of the catchments (Whitfield, 1975; Hollis, 1978; Thompson, 1982; Bradley and Allison, 1985; Allison and Hartnup, 1981).

\section{FIELD EXAMINATION}

The selected areas were visited between December 2000 and March 2001, before the soil structural conditions and associated hydrological effects of that winter (e.g. signs of erosion) were altered by any spring cultivation. Fields were selected at random from those under the same land

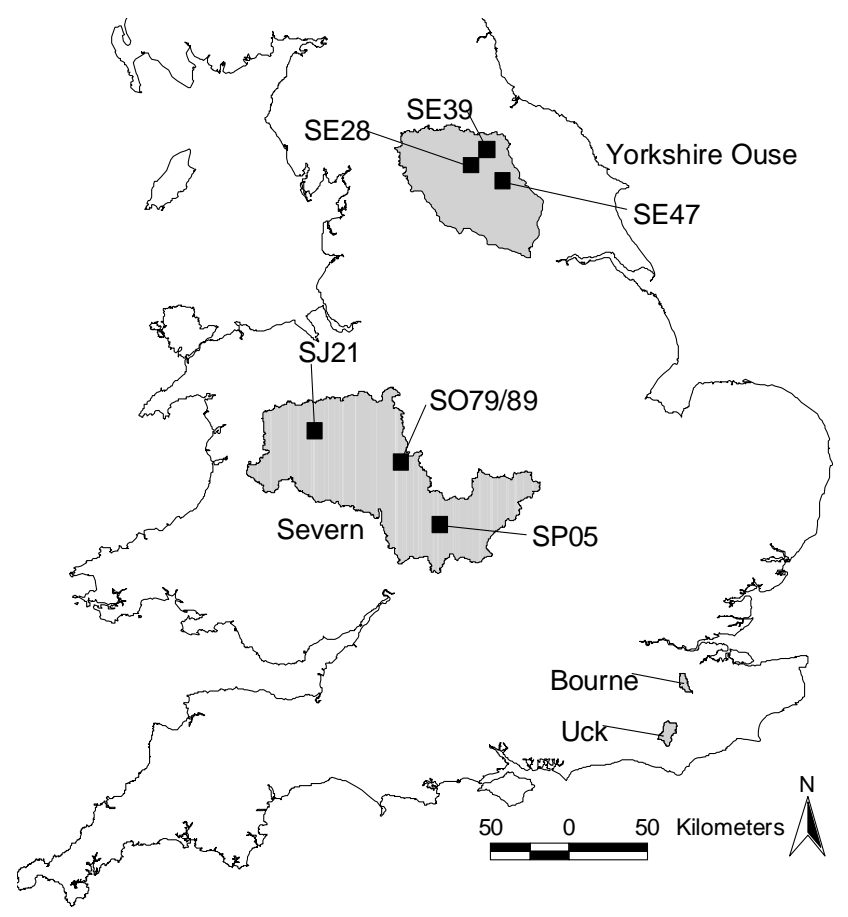

Fig. 1. Location of the study catchments and the representative $10 \mathrm{~km} \times 10 \mathrm{~km}$ blocks chosen to represent the Severn and Yorkshire Ouse catchments 
Table 1. Numbers of fields investigated under different management systems in each study area

\begin{tabular}{|c|c|c|c|c|c|c|c|c|}
\hline \multirow[b]{3}{*}{ Management system } & \multicolumn{7}{|c|}{ CATChMENT } & \multirow{3}{*}{ Bourne } \\
\hline & \multicolumn{3}{|c|}{ Ouse } & \multicolumn{3}{|c|}{ Severn } & \multirow[t]{2}{*}{ Uck } & \\
\hline & SE39 & SE28 & SE47 & SO79/89 & $S J 21$ & SP05 & & \\
\hline Grass (Gr) & 14 & 16 & 9 & 3 & 20 & 11 & 31 & 18 \\
\hline Autumn sown (As) & 9 & 18 & 13 & 14 & 5 & 15 & 22 & 25 \\
\hline Late autumn harvested (Lah) & 14 & 5 & 10 & 21 & 5 & 2 & 11 & 1 \\
\hline Field vegetable (Vf) & 0 & 0 & 0 & 0 & 1 & 9 & 0 & 0 \\
\hline Orchards* (Or) & 0 & 0 & 0 & 0 & 0 & 0 & 14 & 50 \\
\hline Total & 37 & 39 & 32 & 38 & 31 & 37 & 78 & 94 \\
\hline
\end{tabular}

management practice, and were chosen to reflect the approximate proportions of the five land management systems identified in each area, using a stratified random sampling method (Webster, 1993). The numbers of fields inspected under each cropping system in each study area are summarised in Table 1. The percentages of each soil class were fairly representative of those given by the national soil map (Ragg et al., 1984), particularly in the larger catchments.

Crop, soil surface condition, soil moisture state and the characteristics of the topsoil and upper subsoil horizons were recorded using standardised soil surveying procedures (Hodgson, 1997). Soil horizon properties were observed from small trial pits (approximately $30 \times 30 \times 40 \mathrm{~cm}$ ) enabling a clear interpretation of soil structure.

\section{CLASSIFICATION OF THE EXTENT OF SOIL STRUCTURAL DEGRADATION}

Table 2 shows a simple descriptive classification of soil structural degradation. The following characteristics, identified during the field examination, were used to characterise the 'soil degradation features' present and, based on these, each site was allocated to a soil structural degradation class according to specific combinations of features as defined in Table 3:

- Surface soil condition - the presence of a slaked or capped topsoil indicating that the natural infiltration capacity of the soil surface has been reduced (National Soil Resources Institute, 2001);

- Presence of wheeling or tramlines - the passage of vehicles over the soil surface deforms and compacts the upper parts of the topsoil, leading to a reduced infiltration capacity and the creation of preferential pathways for rapid water movement off the land (Chambers and Garwood, 2000; Evans, 1996);
- The extent of poaching — overstocking, or grazing when soil is too wet, leads to poaching and compaction of the upper topsoil (Vallentine, 1990);

- The presence of structural change within, or at the base of, the topsoil - the ill-timed use of some cultivation practices, especially ploughing, can result in the formation of compacted layers within, or at the base of, the topsoil (Ministry of Agriculture, Fisheries and Food, 1998). The overall permeability of the topsoil and/or the topsoil/subsoil junction is reduced, promoting topsoil saturation and lateral water movement;

- The presence of erosion and deposition features indicating that runoff has been sufficiently great to cause the movement of detached soil particles;

- Vertical wetness gradients within the soil profile - in naturally well-drained, permeable soils it would be expected that during the winter months, except shortly after intense rainfall events, the soil profile would be of approximately similar wetness throughout. An indication of structural degradation is provided when such soils are significantly drier in the subsoil, compared to the topsoil.

\section{CLASSIFICATION OF NATURAL SOIL CHARACTERISTICS}

The susceptibility of a soil to structural degradation associated with land management practices is strongly influenced by natural soil physical properties, in particular texture and inherent water regime. For example, soils with a large clay content have lower bearing strength when wet and are therefore more susceptible to compaction and damage during trafficking and cultivation than soils with a small clay content. Conversely, soils with high silt and low clay content are more prone to capping (or crusting) at the surface, associated with the breakdown of soil aggregates. The soils within the catchments and at the selected sites 
Table2. Soil Structural Degradation classes

\begin{tabular}{lll}
\hline Class & Name & Description \\
\hline $\mathrm{S}$ & Severe & $\begin{array}{l}\text { Soil degradation generates sufficient enhanced runoff to cause widespread erosion that is not } \\
\text { confined to wheelings / tramlines. }\end{array}$ \\
$\mathrm{H}$ & High, extensive & Soil degradation generates enhanced runoff across whole field, where slopes allow \\
$\mathrm{M}$ & Moderate, local & Soil degradation generates localised areas of enhanced runoff, where slopes allow \\
$\mathrm{L}$ & Low & Insignificant enhanced runoff generation \\
\hline
\end{tabular}

Table 3. Features associated with the Soil Structural Degradation classification

\begin{tabular}{|c|c|c|}
\hline Class & Management system & Soil degradation features \\
\hline $\mathrm{S}$ & All (As, Lah, Vf, Or, Gr) ${ }^{1}$ & $\begin{array}{l}\text { Extensive rill erosion that is not confined to wheelings on slopes and } \\
\text { depositional fans on footslopes and level ground }+ \text { characteristics of } \\
\text { Class H }\end{array}$ \\
\hline $\mathrm{H}$ & Arable or Orchard (As, Lah, Vf, Or) & $\begin{array}{l}\text { Slaked or capped topsoil + topsoil structural change / compaction or } \\
\text { 'loose' surface / poor load bearing capacity }+ \text { extensive areas of standing } \\
\text { water (not confined to wheelings) + vertical wetness gradient } \pm \text { erosion } \\
\text { in wheelings }\end{array}$ \\
\hline $\mathrm{H}$ & Grassland (Gr) & $\begin{array}{l}\text { Extensively poached surface }+ \text { extensive areas of standing water }+ \text { topsoil } \\
\text { compaction }+ \text { vertical wetness gradient }\end{array}$ \\
\hline M & Arable or Orchard (As, Lah, Vf, Or) & $\begin{array}{l}\text { Slaked or partly slaked topsoil }+ \text { standing water in wheelings } \pm \text { topsoil } \\
\text { structural change }\end{array}$ \\
\hline M & Grassland (Gr) & Slight poaching (locally severe) + localised areas of standing water \\
\hline $\mathrm{L}$ & All (As, Lah, Vf, Or, Gr) & $\begin{array}{l}\text { Few signs of enhanced runoff mechanisms present, but can show signs } \\
\text { of localised poaching and standing water as long as the whole profile } \\
\text { maintains a good soil structure }\end{array}$ \\
\hline
\end{tabular}

have been classified into eight categories (soil classes), according to their natural textural and water regime characteristics (Table 4), to aid the extrapolation of data from representative areas.

\section{EXTRAPOLATION OF THE OBSERVED DATA TO THE CATCHMENTS}

The observed data were extrapolated to the catchment scale using two data sources. Soil data were derived from the digital vector data version of the 1:250,000 scale National Soil Map of England and Wales (Ragg et al., 1984). Cropping statistics were derived from the Department of Environment, Food and Rural Affairs (DEFRA) parish agricultural census data. For areas within England, NUTS5 (ward-level) statistics from the 2000 census data were used. Due to the unavailability of recent individual crop data in Wales, a $2 \mathrm{~km} \times 2 \mathrm{~km}$ gridded dataset of cropping statistics from the 1995 census data had to be used for the area of the Severn catchment within Wales. 
Table 4. Characteristics of the Soil Classes

\begin{tabular}{|c|c|c|}
\hline Soil class & Topsoil texture & Water regime \\
\hline 1 & Sand, loamy sand or sandy loam & $\begin{array}{l}\text { Permeable soils, either freely drained, or experiencing seasonal subsoil } \\
\text { waterlogging due to groundwater }\end{array}$ \\
\hline 2 & Sand, loamy sand or sandy loam & $\begin{array}{l}\text { Experience occasional seasonal waterlogging in upper layers due to slowly } \\
\text { permeable subsoils }\end{array}$ \\
\hline 3 & $\begin{array}{l}\text { Sandy silt loam, silty clay loam, silt loam, } \\
\text { clay loam or sandy clay loam }\end{array}$ & $\begin{array}{l}\text { Permeable soils, either freely drained, or experiencing seasonal subsoil } \\
\text { waterlogging due to groundwater }\end{array}$ \\
\hline 4 & $\begin{array}{l}\text { Sandy silt loam, silty clay loam, silt loam, } \\
\text { clay loam or sandy clay loam }\end{array}$ & $\begin{array}{l}\text { Experience occasional seasonal waterlogging in upper layers due to slowly } \\
\text { permeable subsoils }\end{array}$ \\
\hline 5 & $\begin{array}{l}\text { Sandy silt loam, silty clay loam, silt loam, } \\
\text { clay loam or sandy clay loam }\end{array}$ & $\begin{array}{l}\text { Experience prolonged seasonal waterlogging due to slowly permeable } \\
\text { subsoils or high groundwater levels }\end{array}$ \\
\hline 6 & $\begin{array}{l}\text { Heavy clay loam ( }>27 \% \text { clay }) \text {, sandy clay, } \\
\text { silty clay or clay }\end{array}$ & $\begin{array}{l}\text { Experience occasional seasonal waterlogging in upper layers due to } \\
\text { slowly permeable subsoils }\end{array}$ \\
\hline 7 & $\begin{array}{l}\text { Heavy clay loam }(>27 \% \text { clay }) \text {, sandy clay, } \\
\text { silty clay or clay }\end{array}$ & $\begin{array}{l}\text { Experience prolonged seasonal waterlogging due to slowly permeable } \\
\text { subsoils or high groundwater levels }\end{array}$ \\
\hline 8 & Organic & $\begin{array}{l}\text { Experience prolonged seasonal waterlogging due to slowly permeable } \\
\text { subsoils or high groundwater levels }\end{array}$ \\
\hline
\end{tabular}

The cropping and soil datasets used, which are the only nationally available datasets in the UK, are both statistical datasets which are not fully distributed. They each give the percentages of different crop or soil types within a given area but not their location, and hence cannot be spatially overlain within a Geographic Information System. As similar levels of soil structural degradation were observed in all the areas visited (from south-east England to Wales to northern England) a simple yet robust statistical upscaling method was used at the catchment scale. The extrapolation process for each catchment was as follows:

1. Each site within the catchment was classified according to its cropping system, natural soil characteristics (soil class) and level of soil structural degradation. The proportion of the sites in each soil structural degradation class was determined by both land management system and soil class.

2. The proportions of the land management systems were calculated, based upon the constituent cropping categories.

3. All soil series were assigned to one of the Soil Classes. The proportion of each of these classes was then determined using the 1:250000 scale National Soil Map of England and Wales.

4. The proportion of each land management system within each soil class was calculated by simple proportional combination.

5. The proportion of each soil degradation class within each management system-soil class combination was calculated, using the observed proportions.

6. The proportions of each soil degradation class within each management system-soil class combination were then combined to give the proportions of each soil degradation class within the catchment.

7. The proportions of each soil degradation class were combined with the catchment area to the give the area of each soil degradation class.

\section{Results}

\section{DISTRIBUTION OF OBSERVED SOIL STRUCTURAL DEGRADATION}

Figure 2 shows the number of sites assigned to each soil structural degradation class within each agricultural management system within each catchment. This indicates 


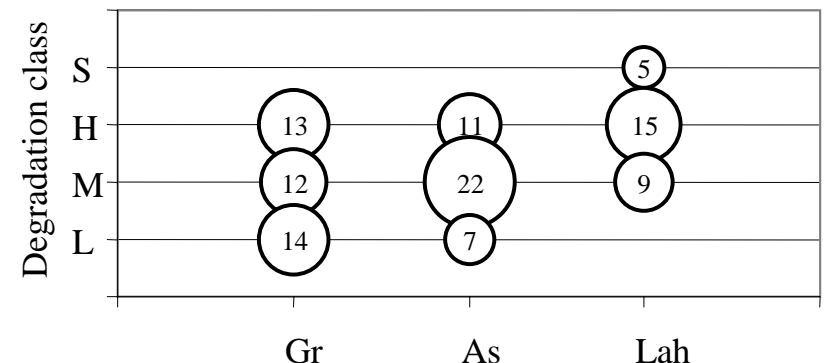

Landuse class

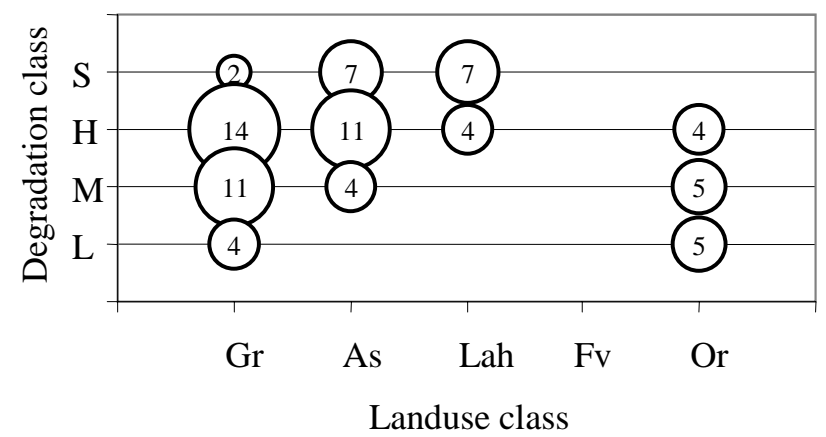

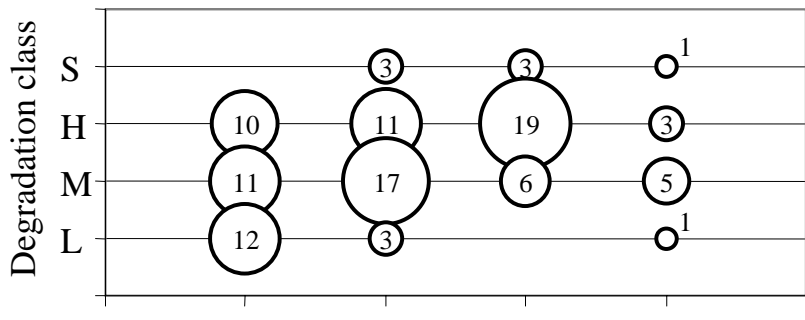

Gr As Lah Fv

Landuse class

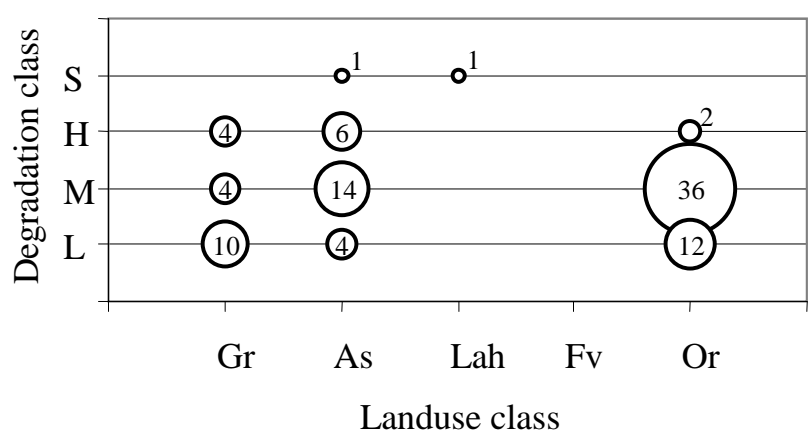

Fig. 2. Distribution of observed Soil Degradation Class by management system in the (top left) Yorkshire Ouse, (top right) Severn, (bottom left) Uck and (bottom right) Bourne catchments

how soil degradation differs between the catchments and management systems.

As a generalisation, the few cases of severe degradation identified are generally confined to sites on autumn-sown or late autumn harvested crops, although some poorly established or heavily poached ley grassland sites are included. The high, moderate and low degradation classes are roughly evenly divided on the grassland sites. In contrast, sites on autumn sown crops have a preponderance of high and moderate degradation, whereas late autumn harvested crops are characterised by high degradation. Sites in orchards have a predominance of moderate degradation, due to the alternating nature of the soil cover characteristics associated with the linear planting.

Figure 3 shows soil structural degradation classes within each soil class within each management system in all catchments. It shows that severe soil structural degradation class is generally most common on soil classes 4 and 5, but is also common for late autumn harvested crops in soil classes 1 and 3 and, to a lesser extent, in soil classes 1 and 2 under autumn sown crops. For most soil classes, there are approximately equal cases of high and moderate soil structural degradation, except for soil class 3 (three times as many moderate cases) and soil class 4 (twice as many high cases).

\section{EXTRAPOLATED SOIL STRUCTURAL DEGRADATION}

The results of the extrapolation are shown in Table 5 for the four catchments. The results for each soil degradation class are expressed as the percentage of the total area of each catchment. The percentages shown do not sum to $100 \%$ for two reasons. Firstly, each catchment contains both nonagricultural areas and areas of cropping systems not considered in this study. Secondly, DEFRA suppresses significant amounts of data in the NUTS5 statistics to maintain farmer confidentiality, especially where the cultivation of a particular crop in an area is dominated by one or two farms. It is likely that the percentage of each cropping system in the catchments, as used in the extrapolation, represents an under-estimate of actual land use. The combined effect of these two factors is shown in Table 6, where the total agricultural area and the combined area of the land management systems of interest to this study are expressed as a proportion of the catchment area. 

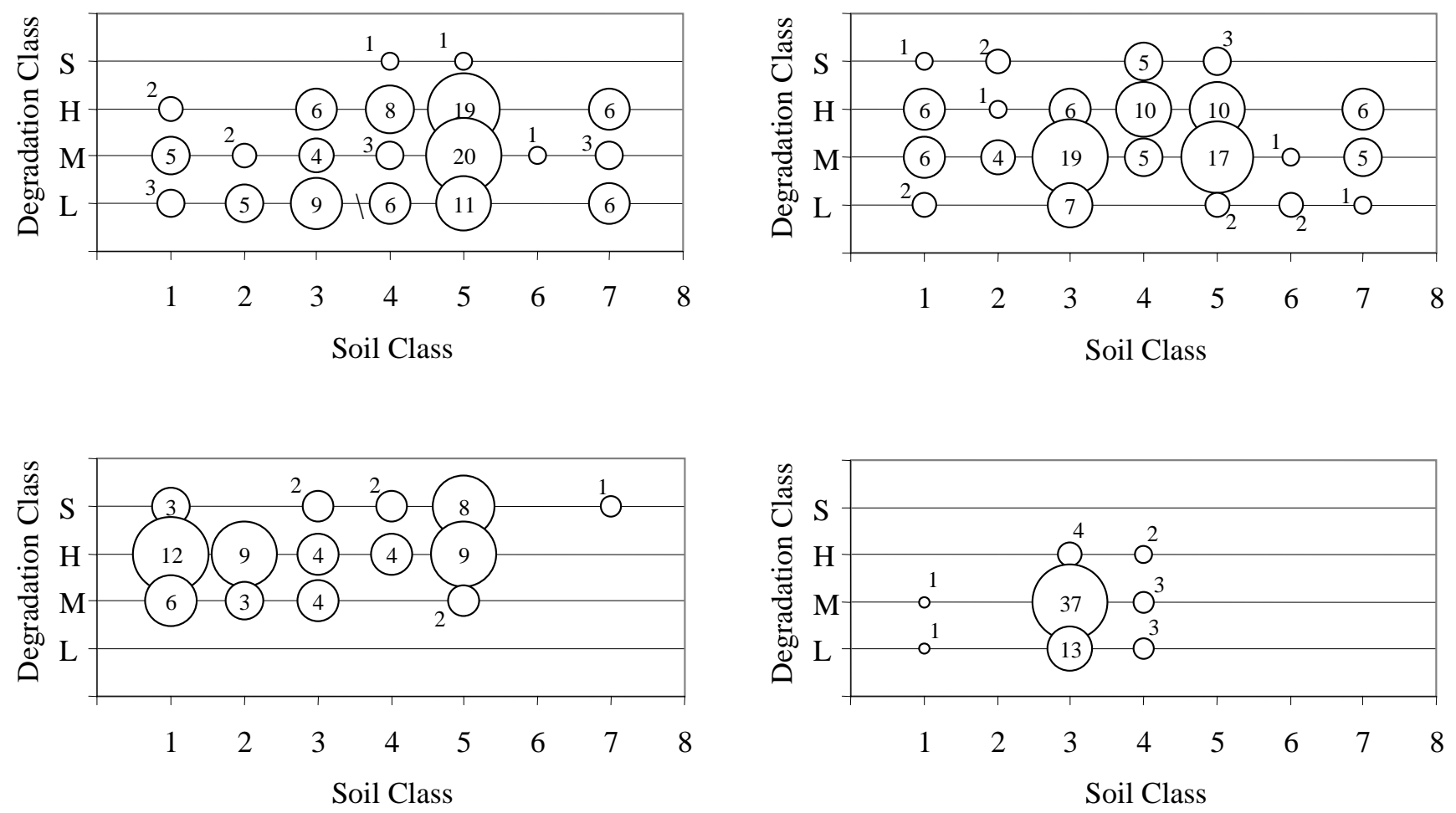

Fig. 3. Distribution of observed Soil Degradation Class by Soil Class in (top left) grassland, (top right) autumn sown cereals, (bottom left) late autumn harvested crops and (bottom right) orchard sites

Table 5. The extrapolated area (sq km) of each Soil Degradation Class within the four catchments studied (percentages of total area in parentheses)

\begin{tabular}{llllll}
\hline \multicolumn{5}{c}{ Soil Degradation Class } \\
& $S$ & $H$ & $M$ & $L$ & Degraded area $(S+H+M)$ \\
\hline Ouse & $35(0.7)$ & $639(13.3)$ & $813(16.9)$ & $491(10.2)$ & $1487(30.9)$ \\
Severn & $47(0.5)$ & $1780(18.5)$ & $2562(26.6)$ & $1233(12.8)$ & $4389(45.6)$ \\
Bourne & $0.2(0.3)$ & $4.2(8.3)$ & $4.9(9.3)$ & $4.4(8.7)$ & $9.3(17.9)$ \\
Uck & $3.7(3.6)$ & $19.7(19.1)$ & $10.7(10.4)$ & $4.3(4.2)$ & $34.1(33.1)$ \\
\hline
\end{tabular}

Table 6. The agricultural area as given by agricultural statistics and the area of the five land management systems, expressed as percentages of the catchment area

\begin{tabular}{llcc}
\hline & $\begin{array}{c}\text { Catchment } \\
\text { area } \\
\left(\mathrm{km}^{2}\right)\end{array}$ & $\begin{array}{c}\text { Agricultural } \\
\text { area } \\
(\%)\end{array}$ & $\begin{array}{c}\text { Target land management } \\
\text { systems } \\
(\%)\end{array}$ \\
\hline Ouse & 4829 & 71 & 50 \\
Severn & 9753 & 73 & 62 \\
Bourne & 53 & 47 & 33 \\
Uck & 103 & 53 & 40 \\
\hline
\end{tabular}

The extrapolation of the site-specific observations to the catchment scale implies that soil structural degradation (as given by Severe, High and Moderate classes) may have occurred over significant areas of land - approximately $45 \%$ of the Severn catchment, $30-35 \%$ of the Yorkshire Ouse and Uck catchments, and $20 \%$ of the Bourne catchment.

POTENTIAL IMPACT OF SOIL STRUCTURAL DEGRADATION

Studies have shown that the impact of soil structural degradation on in-field runoff is significant (e.g. Martyn et 
al., 2000). However, the impact of this soil degradation on river flow response is less clear. There are no regionally applicable methods available in the UK to establish the extent to which stream response to rainfall is modified by land management, soil crusting and soil compaction or the connectivity between field-scale runoff and stream response during storm events. The only method available to link land use and management directly with catchment-scale runoff is the United States Department of Agriculture Curve Number approach (Rallinson, 1980; US Soil Conservation Service, 1986), which is as dependent on land use or cover as it is on the soil type (Institute of Hydrology, 1975).

Although the Curve Number approach does not form a universally applicable model of rainfall and runoff, it is qualitatively relevant to this paper because of the greater influence of storm rainfall, compared to the UK's Flood Studies Report (Institute of Hydrology, 1975). In the absence of quantitative data linking soil degradation with stream response in the UK and the increasing use of the Curve Number in hydrological modelling in the UK and Europe, the Curve Number approach has therefore been used to illustrate the potential magnitude of the hydrological impact of the extrapolated soil structural degradation in the four catchments.

The SCS Runoff Curve Number (CN) method is described in detail in SCS (1985). The SCS runoff equation is

$Q=\frac{\left(P-I_{a}\right)^{2}}{P-I_{a}+S}$

Where $Q$ is the direct surface runoff depth (mm), $I_{a}$ is the initial abstraction $(\mathrm{mm}), P$ is the storm rainfall $(\mathrm{mm})$ and $S$ is the potential maximum retention after runoff begins $(\mathrm{mm})$. $I_{a}$ is empirically linked to $S$ by:

$I_{a}=0.2 S$ so that Eqn. (1) becomes:

$$
Q=\frac{(P-0.2 S)^{2}}{P+0.8 S}
$$

$S$ is related to the soil and cover conditions of the watershed through the Curve Number $(\mathrm{CN})$, which has a range of 0 to 100, by:

$$
S=25.4 *\left(\frac{1000}{C N}-10\right)
$$

The major factors that determine $\mathrm{CN}$ are the Hydrological Soil Group (HSG), cover type, treatment, soil condition and antecedent rainfall condition (ARC). Each soil type within each of the four catchments was assigned to one of the four HSGs based upon a combination of soil texture and runoff potential (as given by the Standard Percentage Runoff of the soil's HOST class; Boorman et al., 1995) in accordance with the descriptions in US SCS (1986).

In determining the potential affect of the soil structural degradation on runoff, Table 7 describes how the soil structural degradation classes have been subjectively linked to $\mathrm{CN}$ factors. The observed severe and high classes equate to a change from Good to Poor soil condition while the observed enhanced topsoil wetness (compared to the underlying unsaturated subsoils) is consistent with a degradation-derived, rather than weather-derived, change from Antecedent Rainfall Condition (ARC) II to III. Figure 4 shows the depth of runoff originating from the combined total areas of the land management systems (as given in Table 5), with and without the observed soil structural degradation, for a range of daily rainfall amounts within those observed in the catchments during the autumn of 2000 .

Also shown for comparison are the equivalent depths of runoff calculated using the UK's Flood Estimation Handbook (FEH) methodology (Reed 1999), which takes into account inherent soil properties (in particular the

Table 7. Linkage of Soil Degradation Classes and land use to CN parameters (cover type, soil condition and Antecedent Rainfall Condition).

\begin{tabular}{llllll}
\hline \multirow{2}{*}{ Land use } & Cover type & Low & Moderate & High & Severe \\
\hline Grass & Pasture & Good'/ARC II & Fair/ARC II & Poor/ARCII & Poor/ARCIII \\
Cereals & Small grains & Good/ARC II & Good/ARC II & Poor/ARCII & Poor/ARCIII \\
Lah \& veg & Row crops & Good/ARC II & Good/ARC II & Poor/ARCII & Poor/ARCIII \\
Top fruit & Woods & Good/ARC II & Fair/ARC II & Poor/ARCII & Poor/ARCIII \\
& & & & & \\
${ }^{1}$ Soil condition & & & & & \\
\hline
\end{tabular}



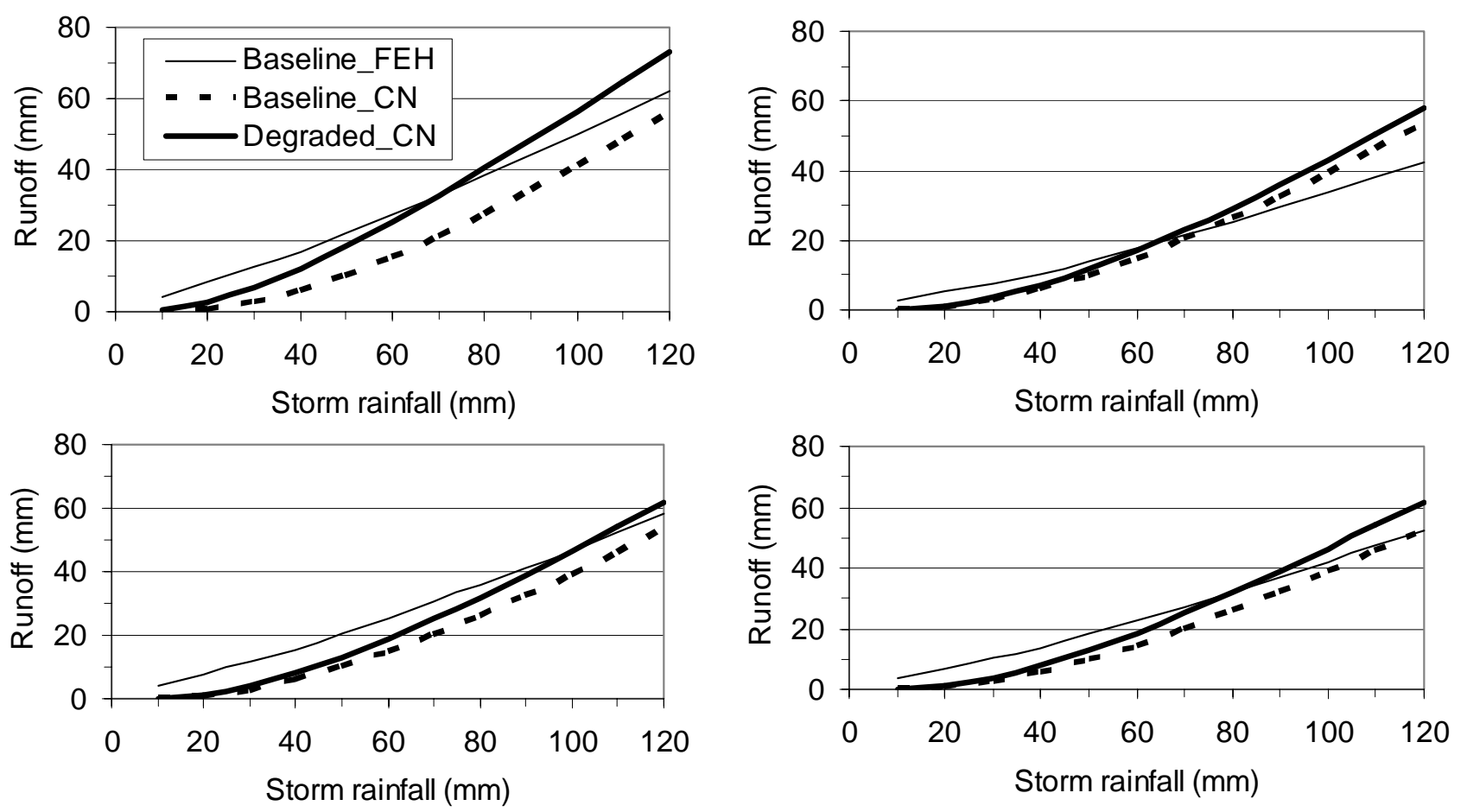

Fig. 4. Potential increase in runoff caused by a soil structural degradation for a range of rainfall events calculated using a Curve Number approach for the (top left) Uck, (top right) Bourne, (bottom left) Yorkshire Ouse and (bottom right) Severn catchments

Standard Percentage Runoff), long term catchment average annual rainfall and event rainfall amount, but not land use or soil condition. Although the estimate of runoff without structural degradation using the Curve Number approach is generally lower than the FEH estimate, the two estimates converge with increasing rainfall amount. At the higher rainfall amounts, the runoff incorporating the observed soil structural degradation is significantly greater than the FEH estimates, and about 10-20 $\mathrm{mm}$ greater than the baseline Curve Number estimate.

\section{Discussion}

Changes in both land use and land management are recognised as potential sources of change to hydrological processes. Land use change research has focused on changes that are either permanent, or long term, such as urbanisation (Cheng and Wang, 2002; Reed, 1999), land drainage (Robinson, 1990; Skaggs et al., 1994) and forestry (e.g. Robinson, 1998; Whitehead and Robinson, 1993), whilst land management research in this area has tended to concentrate on erosion monitoring (e.g. Chambers and Garwood, 2000; Boardman, 1995), erosion control (e.g. Martin, 1999; Fullen, 1998) and phosphorus losses (e.g. Hooda et al., 2000; McDowell et al., 2000).

The observed data described in this paper have shown that soil structural degradation can be more prevalent across a wider range of soil types and land uses than many previous erosion survey studies have shown. Erosion observations have tended to be confined to soils of silty and sandy textures (e.g. Chambers and Garwood, 2000; Boardman et al., 1994) and predominantly under autumn sown arable crops (e.g. Chambers and Garwood, 2000; Boardman, 1995, Boardman et al., 1994). The wider range observed in this study may result from looking at soil structural conditions at the surface, in the topsoil and at topsoil/subsoil junction, as opposed to surface soil conditions which predominantly influence soil erosion. Also, the wet autumn of 2000 caused very great difficulties in harvesting, particularly for root crops, and in autumn crop establishment (ADAS, 2001). This resulted in the late autumn harvested areas and large areas of stubble often being left uncultivated, with larger compensatory areas of spring-sown crops being planted in 2001 (ADAS, 2001).

Unlike urbanisation, land drainage and forestry, soil structural degradation linked to specific agricultural management practices will be spatially and temporally variable. The precise chronology of soil surface changes associated with a land management regime, even for a single field, will change within a season (Imeson and Kwaad, 1990), and from season to season (Burt and Slattery, 1996). Such intra-annual and inter-annual changes in soil structure and infiltration capacity make the identification of any short- 
term effects of soil structural degradation on river flows difficult. They will not occur in the same parts of a catchment at the same time each year nor necessarily generate a consistent increase in runoff, but will depend on the interactions between weather, tillage system, crop type and management on the runoff mechanisms (Burt and Slattery, 1996). The physical changes that are associated with the soil structural degradation reported here are more akin to the changes that occur with urbanisation - an increase in surface sealing and a channelling of flows. The overall effects of such structural degradation are thus similar to those of urbanisation and are likely to have a significant effect on river flows, at least at a local level (Robinson, 1990), but significant impacts will only be apparent when adverse seasonal weather patterns coincide with specific agricultural management practices.

With the lack of quantified data from the UK on river flow response to increased runoff due to soil structural degradation, the results presented in this paper using the $\mathrm{CN}$ approach are only indicative. Nevertheless, the large absolute increases in runoff calculated using the $\mathrm{CN}$ approach supports the potential for soil structural degradation to cause a significant increase in runoff impacting upon peak river flows. However, such a significant response at the catchment-scale is only likely to occur during exceptional years when the combination of prolonged wet weather and the timing of cultivation practices lead to widespread soil structural degradation.

\section{Implications for catchment management}

The cropping and stock management systems observed in the four catchments have been practised for many years, but recent trends towards the use of larger harvesting and cultivation machinery, increased stocking densities and outwintering of sheep, have the potential to increase significantly the structural degradation of soil. The results presented demonstrate that such degradation has indeed occurred in the four catchments and, therefore, will have enhanced field-scale runoff.

By reducing both the overall storage capacity in the soil and the extent of vertical subsurface flow, and by increasing the rate of runoff, the structural degradation is likely to exacerbate the 'normal' response of streams to rainfall. This is likely to have greatest effect during extreme rainfall events at critical times of the year in late autumn, early winter and spring. This has consequent implications for flooding and for mitigation or control measures required to reduce the effects of these higher flows on flooding downstream.

Any such flood mitigation or control measures need to be considered in a catchment-based context within catchment or river basin planning, such as the Catchment Flood Management Planning process that was introduced in England and Wales by DEFRA and the Environment Agency (DEFRA / Environment Agency, 2001). The process provides for the progressive development of policies, strategies and specific flood management solutions.

The role of natural processes, particularly in catchment wetlands (Environment Agency, 2001c) and floodplains, in providing storage and attenuating flood peaks and therefore in reducing flood risks, is already well recognised. This study supports the need for catchment flood management policies and strategies to take the widest possible view of the interactions between land use and hydrology. In general, flood management strategies should seek to control enhanced runoff at source and should therefore support appropriate land management as a flood management solution (Environment Agency, 2001b).

The current debate regarding the future nature of the agricultural industry and its role in the management of the countryside represents an important opportunity to highlight the importance of agricultural land practices for flood management (Holmes, 2001). The future linking of agrienvironmental and set-aside payments with practices that promote the mitigation or control of runoff (e.g. Martin, 1999) could be a valuable addition to the measures discussed within the draft Catchment Flood Management Planning guidelines (DEFRA / Environment Agency, 2001).

\section{Conclusions}

Field examination of soil surface and soil structural conditions showed that soil structural degradation, associated with a number of common cropping systems/ management practices, was present in all four catchments studied. Unlike many previous studies, severe soil structural degradation in the catchments studied was associated with late harvested crops such as maize, sugar beet and, at least during the autumn of 2000, main crop potatoes, as well as autumn-sown crops. High degradation occurred on approximately $55 \%$ of inspected sites with late harvested crops, $30 \%$ of sites under grass, autumn sown crops and field vegetables and $10 \%$ of sites under orchards. The study did not investigate the effects of over-grazing in upland peaty catchments.

Extrapolation to the catchment scale suggests that soil structural degradation may have occurred on approximately $40 \%$ of the Severn, $30-35 \%$ of the Yorkshire Ouse and Uck catchments and $20 \%$ of the Bourne catchment. The lack of quantified data from the UK on river flow response to increased runoff due to soil structural degradation, allowed 
only the Curve Number approach to be used. Soil structural conditions were linked via soil hydrological group, soil condition and antecedent rainfall conditions to SCS Curve Numbers to allow a preliminary evaluation of the possible contribution of enhanced runoff in each catchment. Increased runoff of around $10-20 \mathrm{~mm}$ from the total area of the five land management systems was predicted by the CN approach for large rainfall events in the Severn, Ouse and Uck catchments, and around $5 \mathrm{~mm}$ in the Bourne catchment. The significant predicted responses in increased runoff at the catchment scale are only likely to occur during exceptional years when the combination of prolonged wet weather and the timing of cultivation practices lead to widespread soil structural degradation. Nevertheless, the use of an holistic catchment-wide approach to managing the interactions between agricultural land use and hydrology, allowing appropriate runoff (and consequent flooding) to be controlled at source, rather than within the floodplain or the river channel, should be highlighted in the guidelines on Catchment Flood Management Plans.

\section{Acknowledgements}

The work described in this paper was carried out under Environment Agency R\&D Project no. W5B-026. The authors acknowledge the permission of the Environment Agency to publish, the access granted by the many farmers in the catchments and the contribution made by colleagues in the NSRI and the Environment Agency. Opinions expressed in the paper are those of the authors, and do not necessarily reflect those of their respective organisations.

\section{References}

ADAS, 2001. The Wet Autumn Of 2000: Implications For Agriculture. Report CC0372 for Department of Environment, Food and Rural Affairs.

Allison, J.W. and Hartnup, R., 1981. Soils in North Yorkshire VI (SE39, Northallerton). Soil Survey Record 68.

Arvidsson, J., 2001. Subsoil compaction caused by heavy sugarbeet harvesters in southern Sweden - I. Soil physical properties and crop yield in six field experiments. Soil, Tillage Research 60, 67-78.

Boardman, J., 1991. Land-use, rainfall and erosion risk on the South Downs. Soil Use Manage., 7, 34-38.

Boardman, J., 1995. Damage to property by runoff from agricultural land, South Downs, southern England, 1976-93. Geogr. J. 161, 177-191.

Boardman, J. and Hazelden, J., 1986. Examples of erosion on brickearth soils in east Kent. Soil Use Manage., 2, 105-108.

Boardman, J., Ligneau, L., Deroo, A. and Vandaele, K., 1994. Flooding of property by runoff from agricultural land in northwestern Europe. Geomorphology, 10, 183-196.
Boorman, D.B., Hollis, J.M. and Lilly, A., 1995. Hydrology of Soil Types: A hydrologically-based classification of the soils or the United Kingdom. Institute of Hydrology Report No. 126, Wallingford, UK. 137pp.

Bradley, R.I. and Allison, J.W., 1985. Soils in North Yorkshire VII (SE47, Dalton). Soil Survey Record 87.

Burt, T.P. and Slattery, M.C., 1996. Time-dependent changes in soil properties and surface runoff generation. In: Advances in Hillslope Processes, Volume 1, M.G. Anderson and S.M. Brooks (Eds.). Wiley, Chichester, UK. 79-95.

Chambers, B.J. and Garwood, T.W.D., 2000. Monitoring of water erosion on arable farms in England and Wales, 1990-1994. Soil Use Manage. 16, 93-99.

Cheng, S.J. and Wang, R.Y., 2002. An approach for evaluating the hydrological effects of urbanization and its application. Hydrolog. Process.. 16, 1403-1418.

DEFRA / Environment Agency, 2001. Catchment Flood Management Plans: Interim Guidelines for Consultation and Pilot Catchment Studies. Unpublished report by Halcrow, Swindon.

Earl, R., 1997. Prediction of trafficability and workability from soil moisture deficit. Soil, Tillage Res., 40, 155-168.

Environment Agency, 2001a. Lessons learned: Autumn 2000 floods. Environment Agency, Bristol, UK.

Environment Agency, 2001b. Best Farming Practices: profiting from a good environment. R\&D Publication 23. Environment Agency, Bristol, UK. 57pp..

Environment Agency, 2001c. An Environmental Vision: The Environment Agency's Contribution to Sustainable Development. Environment Agency, Bristol, UK.

Evans, R., 1996. Soil erosion and its impacts in England and Wales. Friends of the Earth, London, UK. $121 \mathrm{pp}$.

Fullen, M.A., 1998. Effects of grass ley set-aside on runoff, erosion and organic matter levels in sandy soils in east Shropshire, UK. Soil Tillage Res., 46, 41-49.

Harrod, T.R., 1994. Runoff, soil erosion and pesticide pollution in Cornwall. In: Conserving Soil Resources: European perspectives, R.J. Rickson (Ed.), CAB International: Wallingford, UK. 425pp.

Haynes, R.J., 1981. Effects of soil management practices on soil physical properties, earthworm populations and tree root distribution in a commercial apple orchard. Soil Tillage, Res., 1, 269-280.

Hodgson, J.M., 1997. Soil survey field handbook. Soil Survey and Land Research Centre Technical Monograph No. 5. Cranfield University: Bedford, UK. 166pp.

Hollis, J.M., 1978. Soils in Salop I (Sheet SO79E/89W, Claverly). Soil Survey Record 49.

Holman, I.P., Hollis, J.M. and Thompson, T.R.E., 2002. Impact of agricultural soil conditions on floods - Autumn 2000. R\&D Technical Report W5B-026/TR, Environment Agency, Bristol, UK.

Holmes, N., 2001. Prospects for flood friendly landscapes. ECOS, 22,58-63.

Hooda, P.S., Edwards, A.C., Anderson, H.A. and Miller, A., 2000. A review of water quality concerns in livestock farming areas. Sci. Tot. Environ., 250, 143-167.

Horton, R., Ankeny, M.D. and Allmaras, R.R., 1994. Effects of compaction on soil hydraulic properties. In: Soil Compaction in Crop Production, B.D. Soane and C. van Ouwerkerk (Eds.) Elsevier, Amsterdam, The Netherlands. 662pp.

Imeson, A.C. and Kwaad, F.J.P.M., 1990. The response of tilled soils to wetting by rainfall and the dynamic character of soil erodibility. In: Soil Erosion on Agricultural Land, J. Boardman, I.D.L. Foster and J.A. Dearing (Eds.) Wiley, Chichester, UK. 3-14. 
Institute of Hydrology, 1975. Flood Studies Report: Volume 1 (Hydrological Studies). Natural Environment Research Council, UK.

Kwaad, F.J.P.M., 1994. Cropping systems of fodder maize to reduce erosion of cultivated Loess soils. In: Conserving Soil Resources: European perspectives, R.J. Rickson (Ed.) CAB International: Wallingford, UK. $425 \mathrm{pp}$.

Martin, P., 1999. Reducing flood risk from sediment-laden agricultural runoff using intercrop management techniques in northern France. Soil Tillage Res., 52, 233-245.

Martyn, T.M., Donaldson, G., Clements, R.O. and Lindsay, J., 2000. Soil erosion control in maize stubbles. Proc. Sixth Research Conf.,, British Grassland Society, 29-30.

McDowell, R.W., Sharpley, A.N., Condron, L.M., Haygarth, P.M. and Brookes, P.C., 2001. Processes controlling soil phosphorus release to runoff and implications for agricultural management. Nutrient Cycling Agroecosys., 59, 269-284.

Ministry of Agriculture, Fisheries and Food, 1998. Code of Good Agricultural Practice for the Protection of Soil (The Soil Code). MAFF Publications: London, UK. 60pp.

National Soil Resources Institute, 2001. A Guide to Better Soil Structure. Cranfield University, Silsoe, UK. 19pp.

Ragg, J.M., Beard, G.R., George, H., Heaven, F.W., Hollis, J.M., Jones, R.J.A., Palmer, R.C., Reeve, M.J., Robson, J.D. and Whitfield, W.A.D., 1984. Soils and their use in Midland and western England. Soil Survey of England and Wales Bulletin No. 12, Harpenden, UK.

Rallinson, R.E., 1980. Origin and evolution of the SCS Runoff Equation. Symposium on Watershed Management. ASCE, New York, USA. 912-924.
Reed, D., 1999. Flood Estimation Handbook Volume 1: Overview. Institute of Hydrology, Wallingford, UK 107pp.

Robinson, M., 1990. Impact of improved land drainage on river flows. Institute of Hydrology Report No. 113. Institute of Hydrology, Wallingford, UK.

Robinson, M., 1998. 30 years of forest hydrology changes at Coalburn: water balance and extreme flows. Hydrol. Earth Syst. Sci., 2, 233-238.

Skaggs, R.W., Breve, M.A. and Gilliam, J.W., 1994. Hydrological and water quality impacts of agricultural drainage. Crit. Rev. Environ. Sci. Technol., 241, 1-32.

Soil Conservation Service. 1985. National engineering handbook. Section 4: Hydrology. Washington, DC, USA.

Thompson, T.R.E., 1982. Soils in Powys II (SJ21, Arddleen). Soil Survey Record 75.

U.S. Soil Conservation Service. 1986. Urban Hydrology for Small Watersheds. Technical Release 55, US Department of Agriculture.

Vallentine, J.F., 1990. Grazing Management. Academic Press, London, UK. 533pp.

Webster, R., 1993. Dealing with spatial variation In: Soil monitoring, R. Schulin, A. Desaules, B. von Stieger and R. Webster (Eds.). Birkhauser Verlag, Basel, Switzerland. 295307.

Whitehead, P.G. and Robinson, M., 1993. Experimental basin studies - an international and historical perspective of forest impacts. J. Hydrol., 145, 217-230.

Whitfield, W.A., 1975. Soils in Warwickshire II (Sheet SP05, Alcester). Soil Survey Record 25. 